BACTERIOLOGICAL NOMENCLATURE

AND TAXONOMY

OPINION NO. 5

CONSERVATION OF THE GENERIC NAME

PSEU DOMONAS MIGULA 1894 AND DESIGNATION OF PSEUDOMONAS AERUGINOSA (SCHROETER) MIGULA 1900 AS TYPE SPECIES

\title{
Judicial Commission
}

The Editorial Board (1) published in the January 1951 is sue of this BULLETIN a Preliminary Statement (File No.7.) relative to the status of the generic name $\mathrm{Pseudomonas}$ Migula 1894, and to the designation of the type species. Three proposals were submitted to the members of the Judicial Commission.

The first proposal was approved by twelve Commissioners, it was disapproved by none, and two Commissioners did not vote.

The second proposal was approved by twelve Commissioners, it was disapproved by none, two Commissioners did not vote.

The third proposal was approved by eleven Commissioners, two Commissioners did not vote, and one Commissioner stated that in his opinion the "selection of type species" is made "in accord with generally accepted rules thus making formal action unnecessary".

The OPINION as approved by the Judicial Commission is as follows:-

OPINION NO. 5 .

1. The generic name $\mathbf{P} \mathbf{s}$ eudomona $\mathbf{s}$ Migula 1894 is to be conserved and placed in the list of nomina generica conservanda.

2. The generic name $\mathrm{Pse}$ u dom on a $\mathrm{s}$ Migula 1894 (2) is to be associated with the species designated and described by Migula 1895 (3).

3. The type species of the genus Pseudomonas Migula 1894 is $P$ seudomonas aeruginosa (Schroeter) Migula $1900(4)(B$ acte $\overline{\text { rium aeru- }}$ ginosum Schroeterl $872(5)$, Bacillus pyocy- 
aneus Gessard 1882 (6), Pseudomonas pyocyanea Migula 1895 (3).

\section{REFERENCES}

(1). Editorial Board. Status of Pseudomonas Migula 1894 (2) as a Generic Name and of Pseudomonas a e ruginos a (Schroeter) Migula 1900 as Type Species Internat. Bull. Bact. Nomencl. and Tax. $1(1): 41-42$. 1951.

(2). Migula, W. Ueber ein neues System der Bakterien. Arb. Bakt. Inst. Karlsruhe. 1:237. 1894.

(3). Migula, W. Schiz omycete- (Bacteria, Bacterien) in Engler, A. and K. Prantl. Die Natürlichen Pflanzenfamilien. Teil 1, Abt. 1a. 29. 1895.

(4). Migula, W. System der Bakterien. 2:884. 1900.

(5). Schroeter, J. Ueber einige durch Bacterien gebildete Pigments, in Cohn, F., Beiträge z. Biologie d. Pflanzen. 1 (Heft 2):126. 1872 .

(6). Gessard, C. Sur les Colorations bleue et verte des linges à pausements. C.R. Acad. Sci. Paris. 94:536. 1882 . 